Pure \& Appl. Chem., Vol. 57, No. 1, pp. 79-88, 1985.

Printed in Great Britain.

(c) 1985 IUPAC

\title{
Metal-ligand bond-energies in organometallic compounds
}

\author{
Henry A. Skinner and Joseph A. Connor \\ Department of Chemistry, University of Manchester, Manchester, U.K., \\ Department of Chemistry, University of Kent, Canterbury, U.K.
}

\begin{abstract}
The energy contributions of metal-carbon and metal-ligand bonds in a variety of organometallic compounds are examined to seek trends as the metal or the ligand changes. In general, the bond energies $\bar{D}(M-X)$ for metals from the same group increase as the energy of atomization of the metal increases. Metal-carbon bond dissociation energies fall along the sequence $D_{0}(M C)$ in diatomic carbides > $\overline{\mathrm{D}}(\mathrm{M}-\mathrm{CP})$ in cyclopentadienyls $>\overline{\mathrm{D}}(\mathrm{M}$-arene $)>\overline{\mathrm{D}}(\mathrm{M}-\mathrm{alkyl})>\overline{\mathrm{D}}(\mathrm{M}-\mathrm{CO})$ in metal carbonyls. For transition metals, the ligand bonding power of phosphine donors $\left(\mathrm{PEt}_{3}>\mathrm{PPh}_{3}\right.$ ) is larger than for nitrogen donors (pyridine $>\mathrm{MeCN}>\mathrm{NH}_{3}$ ), and olefine donors have similar bonding power to $\mathrm{CO}$ and pyridine. The irregular changes in the dissociation energies, $\mathrm{D}_{\mathrm{o}}\left(\mathrm{M}_{2}\right)$, of transition dimetals on moving across the Periodic Table are considered in relation to the 'valence-state' adopted by the metal in forming metal-metal bonds.
\end{abstract}

\section{INTRODUCTION}

The enthalpies of formation of more than 400 organometallic compounds have now been determined; roughly one-half of these were obtained during the past decade, and relate to organo-compounds of the transition-metals. The most recent review (Ref.l) lists the $\Delta \mathrm{H}_{\mathrm{f}}^{\mathrm{O}}$ values for 370 organometallics. Values are also now available for the dissociation-energies of ca. 300 diatomic molecules containing one or more metal atoms, including dimetals and intermetals (Ref.2), M-H, M-C, M-N (Ref.3) and M-O diatomics (Ref.4). The current data-bank is sufficient to seek possible trends in metal-ligand bond energies on passing from one metal to another, along or down the Periodic Table, but there are serious gaps and for some metals (e.g. lanthanides) very little is known.

\section{DEFINITIONS AND SYMBOLS}

The term 'bond energy' is widely used, but it needs to be defined. For a gaseous diatomic molecule, $M X$, the energy $\left(\Delta_{\mathrm{D}}\right)$ of the dissociation process $M X(g) \rightarrow M(g)+X(g)$ is temperature dependent. The symbol $\mathrm{D}_{0}$ is used for the dissociation energy at the absolute zero, and $\mathrm{D}$ for the dissociation energy at $298 \mathrm{~K} . \Delta \mathrm{H}_{\mathrm{D}}^{\circ}$ refers to the standard enthalpy of dissociation at $298 \mathrm{~K}$, i.e.

Do = dissociation energy at $0 \mathrm{~K}$

$\mathrm{D}(\mathrm{MX})=$ dissociation energy at $298 \mathrm{~K}$

$\Delta \mathrm{H}_{\mathrm{D}}^{\circ}(\mathrm{MX})=$ dissociation enthalpy at $298 \mathrm{~K}$

For a polyatomic molecule $\mathrm{MX}_{\mathrm{n}}(\mathrm{X}=$ atom), in the gaseous form,

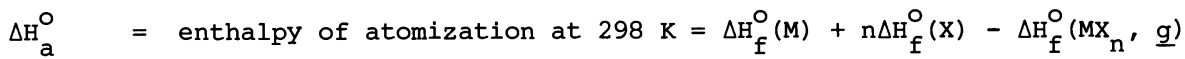

$\Delta \mathrm{U}_{\mathrm{a}}^{\circ}=$ energy of atomization at $298 \mathrm{~K}=\Delta \mathrm{H}_{\mathrm{a}}^{\circ}-\mathrm{nRT}=\Delta \mathrm{H}_{\mathrm{a}}^{\circ}-2.48 \mathrm{n} \mathrm{kJ} \mathrm{mol}{ }^{-1}$

$\bar{D}(M-X)=$ mean bond-dissociation energy $=\Delta \mathrm{U}_{\mathrm{a}}^{0} / \mathrm{n}$ 
For a molecule $\mathrm{MR}_{n}$, where $\mathrm{R}$ is a free radical (e.g. in $\mathrm{Sn}\left(\mathrm{CH}_{3}\right)_{4}, \mathrm{R}=. \mathrm{CH}_{3}=\mathrm{Me}$ ), the enthalpy of the disruption process, $\mathrm{MR}_{\mathrm{n}}(\mathrm{g}) \rightarrow \mathrm{M}(\mathrm{g})+\mathrm{nR}(\mathrm{g})$ at $298 \mathrm{~K}$ is represented by $\Delta \mathrm{H}_{\mathrm{dis}}^{\circ}$, i.e.

$\Delta \mathrm{H}_{\text {dis }}^{\mathrm{O}}=$ enthalpy of disruption $=\Delta \mathrm{H}_{\mathrm{f}}^{\mathrm{O}}(\mathrm{M})+\mathrm{n} \Delta \mathrm{H}_{\mathrm{f}}^{\mathrm{O}}(\mathrm{R})-\Delta \mathrm{H}_{\mathrm{f}}^{\mathrm{O}}\left(\mathrm{MR}{ }_{\mathrm{n}}, \mathrm{g}\right)$

$\Delta \mathrm{U}_{\text {dis }}^{\circ}=$ energy of disruption $=\Delta \mathrm{H}_{\text {dis }}^{\circ}-2.48 \mathrm{n}$

$\bar{D}(M-R)=$ mean bond-dissociation energy $=\Delta U_{\mathrm{dis}}^{\circ} / \mathrm{n}$

For a molecule in which the metal is bonded to different ligands, e.g. $\left[\left(\mathrm{Et}_{3}{ }^{\mathrm{P})}{ }_{2} \mathrm{PtCl}_{2}\right]\right.$, the disruption process has $\Delta \mathrm{U}_{\mathrm{dis}}^{\circ}=2 \overline{\mathrm{D}}(\mathrm{Pt}-\mathrm{Cl})+2 \overline{\mathrm{D}}\left(\mathrm{Et}_{3} \mathrm{P} \rightarrow \mathrm{Pt}\right)$ and the evaluation of the individual $\bar{D}$ values requires acceptance of a 'transfer' value (e.g. $\bar{D}(\mathrm{Pt}-\mathrm{Cl})$ from $\mathrm{PtCl}_{4}$ ) for one of them. The partial disruption reaction, $\left.\left[\left(\mathrm{Et}_{3} \mathrm{P}\right)_{2} \mathrm{PtCl}_{2}\right] \rightarrow 2 \mathrm{Et}_{3} \mathrm{P}+\mathrm{PtCl}_{2}\right)(\mathrm{g})$ has $\Delta \mathrm{H}_{\mathrm{r}}^{\mathrm{O}}=2 \Delta \mathrm{H}_{\mathrm{f}}^{\circ}\left[\mathrm{Et}_{3} \mathrm{P}\right]+\Delta \mathrm{H}_{\mathrm{f}}^{\circ}\left[\mathrm{PtCl}_{2}\right]-\Delta \mathrm{H}_{\mathrm{f}}^{\circ}\left[\left(\mathrm{Et}_{3} \mathrm{P}\right)_{2} \mathrm{PtCl}_{2}\right]$ and enables a direct measure of the mean bond-disruption energy, $\bar{D}\left(E_{3} P-\mathrm{PtCl}_{2}\right)=\Delta \mathrm{U}_{r}^{\mathrm{O}} / 2$. For this same molecule, now written as Pt $\mathrm{P}_{2} \mathrm{C}_{12} \mathrm{H}_{30} \mathrm{Cl}_{2}$, the enthalpy of atomization, $\Delta \mathrm{H}_{\mathrm{a}}^{\circ}$, is given by $\Delta \mathrm{H}_{\mathrm{a}}^{\mathrm{O}}=\Delta \mathrm{H}_{\mathrm{f}}^{\mathrm{O}}(\mathrm{Pt})+2 \Delta \mathrm{H}_{\mathrm{f}}^{\mathrm{O}}(\mathrm{P})+12 \Delta \mathrm{H}_{\mathrm{f}}^{\mathrm{O}}(\mathrm{C})+30 \Delta \mathrm{H}_{\mathrm{f}}^{\mathrm{O}}(\mathrm{H})+2 \Delta \mathrm{H}_{\mathrm{f}}^{\mathrm{O}}(\mathrm{Cl})-\Delta \mathrm{H}_{\mathrm{f}}^{\mathrm{O}}\left(\mathrm{PtP}_{2} \mathrm{C}_{12} \mathrm{H}_{30} \mathrm{Cl}_{2}\right)$, and $\Delta \mathrm{U}_{\mathrm{a}}^{\circ}=\Delta \mathrm{H}_{\mathrm{a}}^{\circ}-46 \times 2.48 \mathrm{~kJ} \mathrm{~mol}{ }^{-1}$

On the basis of "bond-additivity", $\Delta_{a}^{\circ}$ is equated to the sum of the bond-energy contributions in the molecule, e.g.,

$\left.\Delta \mathrm{U}_{\mathrm{a}}^{\mathrm{O}}=2 \mathrm{E}(\mathrm{Pt}-\mathrm{Cl})+2 \mathrm{E}(\mathrm{Pt}-\mathrm{P})+6 \mathrm{E}(\mathrm{P}-\mathrm{C})+6 \mathrm{E}(\mathrm{C}-\mathrm{C})+12 \mathrm{E}(\mathrm{C}-\mathrm{H}), \mathrm{sec}\right)+18 \mathrm{E}(\mathrm{C}-\mathrm{H}$, primary $)$

and the evaluation of the individual $\mathrm{E}$ values is an arbitrary process, depending on the distribution rules of the scheme (Ref.5) adopted in apportioning $\Delta \mathrm{U}_{a}^{\circ}$ among the bonds present
in the molecule.

\section{AUXILIARY DATA}

The evaluation of $\overline{\mathrm{D}}$ or $\mathrm{E}$ values in organometallic compounds from their enthalpies of formation also requires $\Delta \mathrm{H}_{\mathrm{f}}^{\circ}$ values for gaseous metal atoms, and for ligands or free radicals bonded to the metal. The auxiliary data for the metals, listed in Table 1 , are based on the critical compilations by Glushko and Gurvich (6), Glushko and Medvedev (7), Kondratiev (8), and the N.B.S. Selected values (9) ; some of the values for free radicals are included in a recent review (Ref.10). Error limits are not quoted in Table 1, but for values where the uncertainty exceeds $\pm 10 \mathrm{~kJ} \mathrm{~mol}-1$, an asterisk is attached.

\section{METAL HYDRIDES, ALKYLS AND ARYLS}

Thermochemical and bond-energy values are known for several hydrides, $\mathrm{MH}_{\mathrm{n}}$, alkyls and aryls, $M_{n}$, of metals from Group $1-V$ of the Periodic Table, but only a few such values have been determined for $\mathrm{M}-\mathrm{H}$ or $\mathrm{M}-\mathrm{R}$ bonds in transition metal compounds. The available data have been discussed by Pilcher $(1,11)$, and a correlation with the enthalpies of atomization of the metals concerned was noted. Figure 1 shows this for the $\bar{D}(M-H), \bar{D}(M-M e), \bar{D}(M-E t)$ and $\bar{D}(M-P h)$ values $(M=S i, G e, S n, P b)$, plotted against $\Delta \mathrm{H}_{\mathrm{f}}^{\circ}(\underline{g})$ for these Group IV elements. In the case of $\mathrm{Si}, \mathrm{Ge}$, and $\mathrm{Sn}$ (all of which adopt a stable 'diamond' lattice in the solid state), $\Delta \mathrm{H}_{\mathrm{f}}^{\circ}(\mathrm{g})$ of the metal is twice the $M-M$ single-bond energy, so that the plot, in effect, implies that $\bar{D}(M-H)$ and $\bar{D}(M-R)$ increase as $\bar{D}(M-M)$ increases. It is interesting that $\mathrm{Pb}$ (which does not adopt a diamond structure in the solid state), fits the same correlation curve. Figure $\frac{2}{2}$ shows a similar plot for the Group $\mathrm{V}$ elements $(\mathrm{M}=\mathrm{P}, \mathrm{As}, \mathrm{Sb}, \mathrm{Bi})$. In the solid state, $\mathrm{As}, \mathrm{Sb}$ and $\mathrm{Bi}$ have the same rhombohedral structure whereas $\mathrm{P}$ is orthorhombic, and $\Delta \mathrm{H}_{\mathrm{f}}^{\circ}(\mathrm{g})$ of the metal
is approximately $1.5 \mathrm{E}(\mathrm{M}-\mathrm{M})$. 
TABLE 1. Auxiliary data; $\Delta \mathrm{H}_{\mathrm{f}}^{\circ}$ values in $\mathrm{kJ} \mathrm{mol}^{-1}$

\begin{tabular}{|c|c|c|c|c|c|c|c|}
\hline $\mathrm{H}$ & 218.0 & $\mathrm{v}$ & 517.3 & $\mathrm{Rh}$ & 557.0 & но & 300.8 \\
\hline $\mathrm{Li}$ & 159.3 & $\mathrm{Cr}$ & 397.1 & $\mathrm{Pd}$ & 375 & Er & 317.1 \\
\hline $\mathrm{Be}$ & 324.0 & $\mathrm{Mn}$ & 284 & $\mathrm{Ag}$ & 284.9 & $\operatorname{Tm}$ & $232.2^{\star}$ \\
\hline 5 & 565.1 & $\mathrm{Fe}$ & 417.1 & $\mathrm{Cd}$ & 111.8 & $\mathrm{Yb}$ & 152.1 \\
\hline 7 & 716.7 & Co & 426.5 & In & 240.4 & $\mathrm{Lu}$ & 427.6 \\
\hline $\mathrm{N}$ & 472.7 & $\mathrm{Ni}$ & 429.5 & $\mathrm{Sn}$ & 301.2 & $\mathrm{Hf}$ & 622.4 \\
\hline 0 & 249.2 & $\mathrm{Cu}$ & 337.6 & $\mathrm{Sb}$ & 265 & $\mathrm{Ta}$ & 782.5 \\
\hline $\mathrm{F}$ & 79.4 & $\mathrm{Zn}$ & 130.5 & I & 106.8 & w & 855 \\
\hline $\mathrm{Na}$ & 107.5 & $\mathrm{Ga}$ & 272.0 & $\mathrm{Cs}$ & 76.5 & $\mathrm{Re}$ & $775^{\star}$ \\
\hline Mg & 147.1 & $\mathrm{Ge}$ & 371.8 & $\mathrm{Ba}$ & 179.0 & Os & $790^{*}$ \\
\hline $\mathrm{Al}$ & 329.7 & As & 301.8 & $\mathrm{La}$ & 430.0 & Ir & $665.3^{*}$ \\
\hline $\mathrm{Si}$ & $450.0^{\star}$ & $\mathrm{Br}$ & 111.9 & $\mathrm{Ce}$ & $423^{*}$ & Pt & 565.7 \\
\hline$P$ & 316.4 & $\mathrm{Rb}$ & 80.9 & Pr & 355.6 & $\mathrm{Au}$ & 368.8 \\
\hline $\mathrm{s}$ & 277.0 & $\mathrm{Sr}$ & 160.5 & Na & 327.6 & $\mathrm{Hg}$ & 61.4 \\
\hline $\mathrm{Cl}$ & 121.3 & $\mathrm{Y}$ & 423.8 & $\mathrm{Sm}$ & 206.7 & $\mathrm{Tl}$ & 181 \\
\hline K & 89.0 & $\mathrm{Zr}$ & 599.3 & $\mathrm{Eu}$ & 175.3 & $\mathrm{~Pb}$ & 195.2 \\
\hline $\mathrm{Ca}$ & 177.8 & $\mathrm{Nb}$ & $723.1^{*}$ & Gd & 397.5 & $\mathrm{Bi}$ & 208 \\
\hline Sc & 377.7 & Mo & 657.6 & $\mathrm{~Tb}$ & 388.7 & Th & 602.0 \\
\hline $\mathrm{Ti}$ & 473.7 & $\mathrm{Ru}$ & $645^{\star}$ & Dy & 290.4 & $\mathrm{U}$ & $535.6^{\star}$ \\
\hline $\mathrm{CH}_{3}$ & \multicolumn{2}{|l|}{$144 \pm 3$} & $\mathrm{Ph}$ & $332 \pm 12$ & OiPr & \multicolumn{2}{|c|}{$-59.5 \pm 8$} \\
\hline $\mathrm{C}_{2} \mathrm{H}_{5}$ & \multicolumn{2}{|l|}{$117 \pm 5$} & $\mathrm{C}_{5} \mathrm{H}_{5}$ & $264 \pm 9$ & $\mathrm{NMe}_{2}$ & \multicolumn{2}{|c|}{$123.5 \pm 8$} \\
\hline $\mathrm{tBuCH}_{2}$ & \multicolumn{2}{|l|}{$30 \pm 6$} & DMP & $(20 \pm 20)$ & $\mathrm{NEt}_{2}$ & \multicolumn{2}{|c|}{$69.4 \pm 8$} \\
\hline \multirow[t]{2}{*}{$\mathrm{PhCH}_{2}$} & \multirow[t]{2}{*}{$204 \pm 4$} & & $\operatorname{mhp}$ & $(25 \pm 20)$ & OAC & \multirow{2}{*}{\multicolumn{2}{|c|}{$\begin{array}{l}-(227 \pm 10) \\
-(202 \pm 20)\end{array}$}} \\
\hline & & & & & acac & & \\
\hline
\end{tabular}

(DMP $=\mathrm{m}$-dimethoxyphenyl $; \mathrm{mph}=2$-oxy 6 methylpyridine $)$

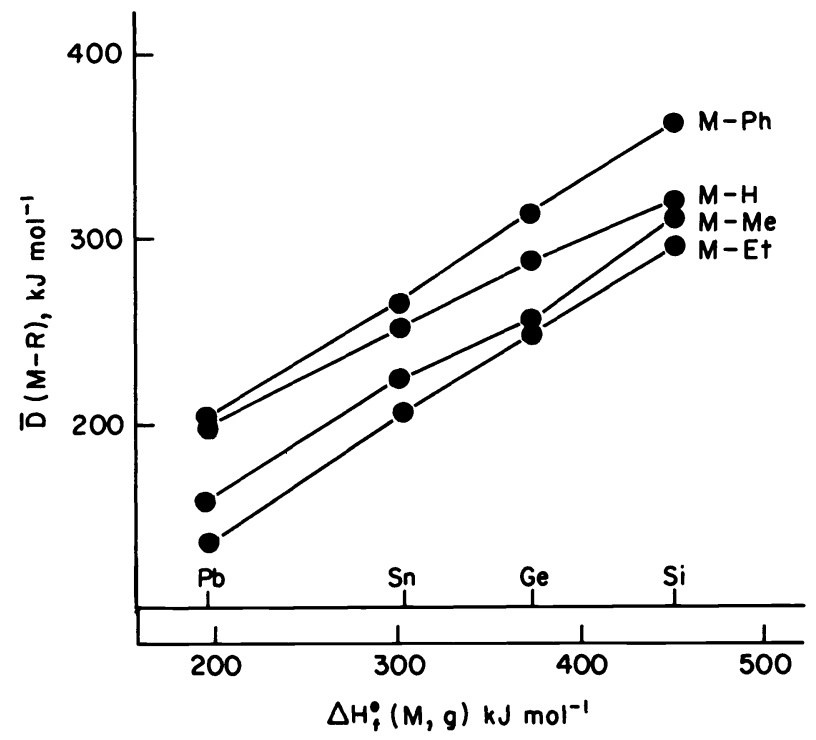

Figure 1. $\bar{D}(M-H), \bar{D}(M-R) \vee \Delta H_{f}^{O}(M)$ for Group IV metals 


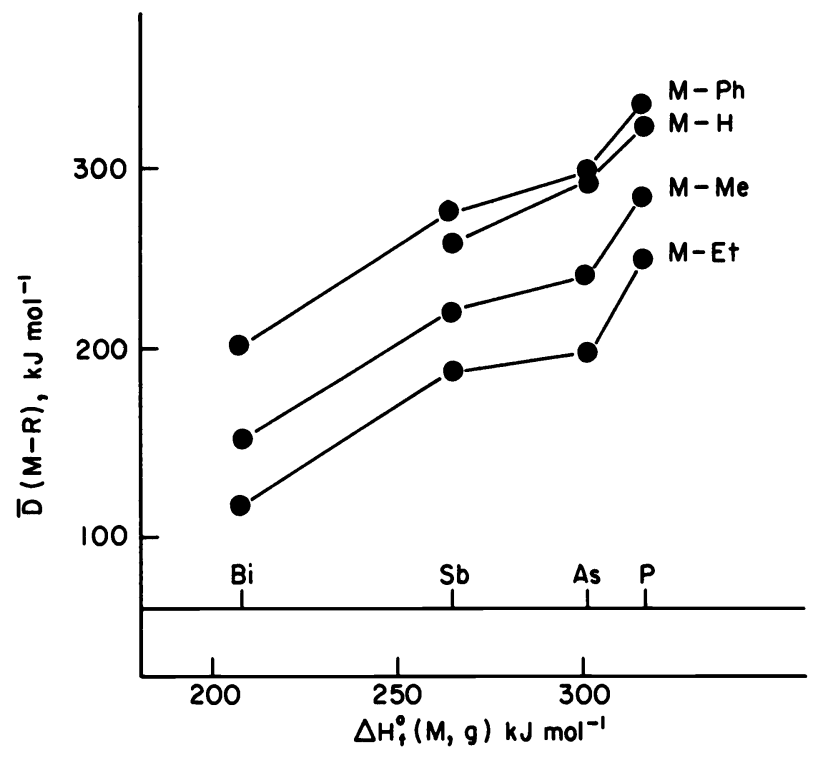

Enthalpies of formation have been reported for compounds $\mathrm{MR}_{4}$ of the transition-metals $M=\mathrm{Ti}, \mathrm{Zr}$, Hf (Ref. 12), for $\mathrm{R}=$ neopentyl $\left(\mathrm{Me}_{3} \mathrm{CCH}_{2}\right), \mathrm{PhCH}_{2}, \mathrm{NEt}_{2}$, OiPr. The derived mean bond-dissociation energies, $\bar{D}(M-R)$,

$\begin{array}{llllllll}\text { Ti-Np } & 185 & \text { TiBz } & 217 & \text { Ti-NEt }_{2} & 307 & \text { Ti-OiPr } & 447 \\ \text { Zr-Np } & 221 & \text { Zr-Bz } & 263 & \text { Zr-NEt }_{2} & 337 & \text { Zr-OiPr } & 517 \\ \text { Hf-Np } & 240 & & & \text { Hf-NEt }_{2} & 364 & \text { Hf-OiPr } & 535\end{array}$

plotted against $\Delta \mathrm{H}_{\mathrm{f}}^{\circ}(\mathrm{g})$ of the metals, are shown in Figure 3. The dissociation-energies $D(M O)$ and $D(M N)$ of diatomic $M O$ and $M N$ are also plotted in Figure 3 , and show a similar pattern. The metals $\mathrm{Ti}, \mathrm{Zr}$ and $\mathrm{Hf}$ all have the same crystal form (c.p. hexagonal) at room temperature.

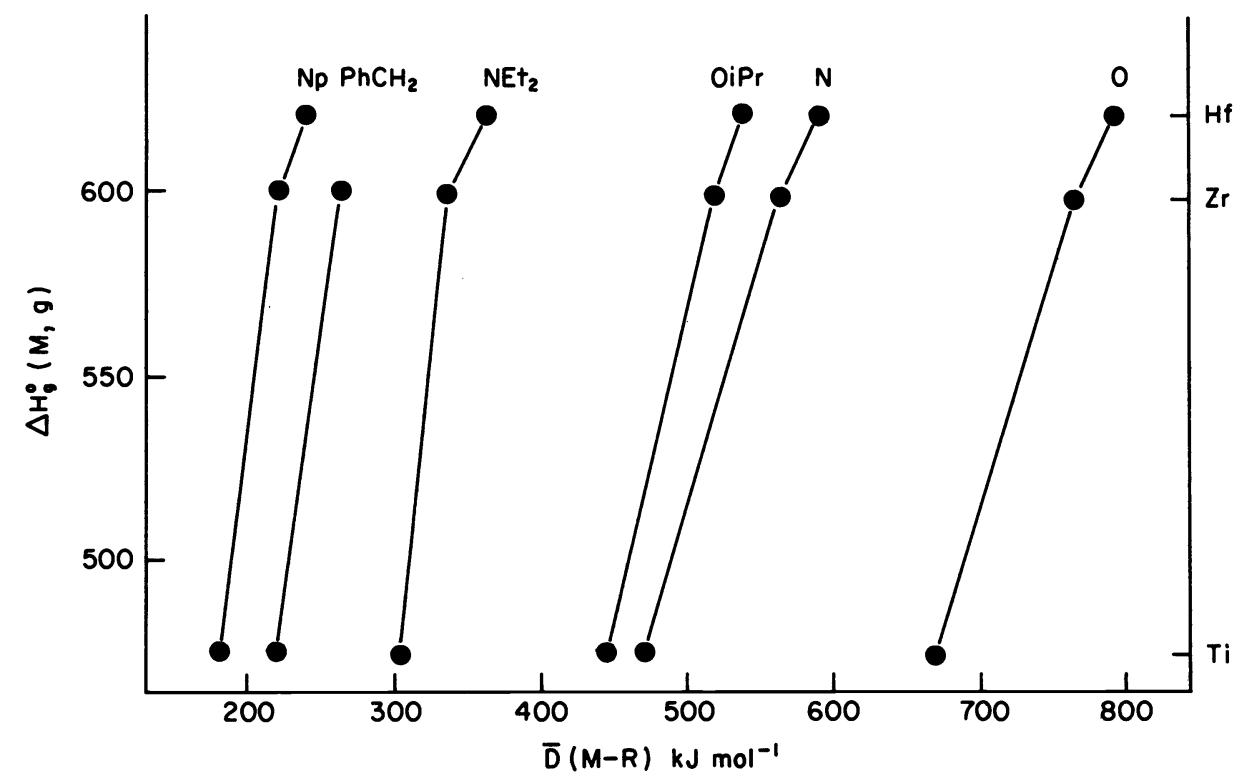

Figure 3. $\bar{D}(M-R)$ values $v \Delta H_{f}^{O}(M)$ for $T i, Z r, H f$. 
METAL CARBONYLS

The enthalpies of formation of the mononuclear carbonyls, $\mathrm{M}(\mathrm{CO})_{\mathrm{n}}$, of $\mathrm{Cr}, \mathrm{Mo}, \mathrm{W}, \mathrm{Fe}$ and $\mathrm{Ni}$ lead directly to $\bar{D}(M-C O)$ values for these metals. A pulsed laser pyrolysis technique has (Ref. 13), recently been applied to study the gas-phase thermal decomposition kinetics of mononuclear carbonyls, and provided values for the first bond dissociation energies, $D_{1}, e . g .$,

$$
\left[\mathrm{Cr}(\mathrm{CO})_{6}, \mathrm{~g}\right] \rightarrow\left[\mathrm{Cr}(\mathrm{CO})_{5}, \mathrm{~g}\right]+\mathrm{CO}(\mathrm{g}) ; \mathrm{D}_{1} \sim 151.5 \mathrm{~kJ} \mathrm{~mol}^{-1}
$$

These differ significantly from the mean $\bar{D}$ values, viz.

$\begin{array}{cccccc} & \mathrm{Cr}(\mathrm{CO})_{6} & \mathrm{Mo}_{(\mathrm{CO})}{ }_{6} & \mathrm{~W}_{(\mathrm{CO})}{ }_{6} & \mathrm{Fe}(\mathrm{CO})_{5} & \mathrm{Ni}(\mathrm{CO})_{4} \\ \overline{\mathrm{D}} & 105 & 149 & 176 & 116 & 144 \\ \mathrm{D}_{1} & 152 & 167 & 190 & 171 & 102\end{array}$

and in an irregular fashion. Variations of this order of magnitude are not uncommon; in the case of the dialkyls of $\mathrm{Zn}, \mathrm{Cd}$ and $\mathrm{Hg}$ (Ref. 14), $\mathrm{D}_{1} \gg \overline{\mathrm{D}}>\mathrm{D}_{2}$, and in $\mathrm{CH}_{4}, \mathrm{D}_{1}$ exceeds $\mathrm{D}_{4}$ by nearly $100 \mathrm{~kJ} \mathrm{~mol}^{-1}$. Such differences are to be expected in molecules $\mathrm{MR}_{\mathrm{n}}$ where the

'valence-state' of $M$ differs from the ground-state of the atom, since the excitation energy required to achieve it is recovered during stepwise dissociation, but not uniformly at each step. The valence-states of $\mathrm{Cr}, \mathrm{Fe}$ and $\mathrm{Ni}$ in the carbonyls $\left(\mathrm{Cr}(\mathrm{CO})_{6}, \mathrm{Fe}(\mathrm{CO})_{5}\right.$ and $\mathrm{Ni}(\mathrm{CO})_{4}$ are considered to derive from zero-valent $d^{6}, d^{8}$ and $d^{10}$ configurations of these atoms; the excitation energies required with $\mathrm{Cr}$ and $\mathrm{Fe}$ are quite high (Ref. 15), whereas the $\mathrm{v}_{\circ}, \mathrm{d}^{10}$ valence-state of $\mathrm{Ni}$ lies only $176 \mathrm{~kJ} \mathrm{~mol}^{-1}$ above the ground-state, $3 \mathrm{~F}$. This is consistent with $\mathrm{D}_{1}>\overline{\mathrm{D}}$ in $\mathrm{Cr}(\mathrm{CO})_{6}$ and $\mathrm{Fe}(\mathrm{CO})_{5}$ by a substantial amount. The excitation energy to reach $\mathrm{V}_{\mathrm{o}^{\prime}} \mathrm{d}^{6}$ in Mo is almost certainly less than with $\mathrm{Cr}$ (the state ${ }^{1} \mathrm{I}, \mathrm{d}^{6}$ in Mo lies $473 \mathrm{~kJ} \mathrm{~mol}^{-1}$ above ground-level, whereas the corresponding state in $\mathrm{Cr}$ has not been observed, and probably lies above the ionization limit). The finding that $\left(D_{1}-\bar{D}\right)$ in $\mathrm{Mo}(\mathrm{CO})_{6}$ is less than in $\operatorname{Cr}(\mathrm{CO}){ }_{6}$ may reflect this. States of configuration $d^{6}$ have not been identified in the atomic spectrum of $\mathrm{w}$. The reverse situation $\left(\mathrm{D}_{1}>\overline{\mathrm{D}}\right)$ in $\mathrm{Ni}(\mathrm{CO})_{4}$ suggests a change in valence-state from $\mathrm{v}_{\circ}, \mathrm{d}^{10}$, in $\mathrm{Ni}(\mathrm{CO})_{4}$ to $\mathrm{v}_{2}, \mathrm{~d}^{8} \mathrm{~s}^{2}$, in $\mathrm{Ni}(\mathrm{CO})_{3}$, with a simultaneous drop in excitation energy from 176 to $88 \mathrm{~kJ} \mathrm{~mol}^{-1}$ (Ref. 15). This would require that the $\mathrm{Ni}(\mathrm{CO})_{3}$ radical has a triplet ground-state.

The thermochemical data on polynuclear carbonyls (e.g. $\mathrm{Mn}_{2}(\mathrm{CO})_{10}, \mathrm{Ru}_{3}(\mathrm{CO})_{12}, \mathrm{lr}_{4}(\mathrm{CO})_{12}$ ) do not provide $\bar{D}(\mathrm{M}-\mathrm{CO})$ values directly, but have been used by Connor et al (16), on the basis of a subdivision of metal-carbonyl bonds into 'terminal' ( $M-C O$ ) and 'bridging' (M-CO-M) types, to obtain bond-energy contributions in these moelcules. Figure 4 shows a plot of 'terminal' bond energy values against $\Delta_{\mathrm{f}}^{\mathrm{O}}(\mathrm{g})$ for the metals; the value for Os-CO may be too low, since the thermal decomposition studies on $\mathrm{Os}_{3}(\mathrm{CO}) 12$ were not conclusive, and should be re-examined.

\section{METAL ARENES AND CYCLOPENTADIENYLS}

Enthalpies of formation have been determined (Ref. 17, 18) for a number of bis-arenes of $\mathrm{Cr}$, and for bis-benzene Mo and bis-toluene $w$. The derived mean bond dissociation energies, $\overline{\mathrm{D}}\left(\mathrm{Cr}\right.$-arene), depend on the arene, and range from ca. $164 \mathrm{~kJ} \mathrm{~mol}{ }^{-1}$ in $\left[\mathrm{Cr}\left(\mathrm{C}_{6} \mathrm{H}_{6}\right)_{2}\right]$ to $144 \mathrm{~kJ} \mathrm{~mol}^{-1}$ in bis-naphthalene $\mathrm{Cr}$. The $\overline{\mathrm{D}}$ values along the series $\left[\mathrm{Cr}\left(\mathrm{C}_{6} \mathrm{H}_{6}\right)_{2}\right] \rightarrow$

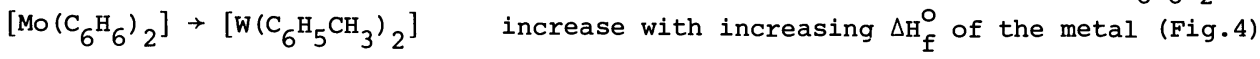

The enthalpies of formation of tris-cyclopentadienyls of Sc, Y, La, Pr, Tm and Yb, and of bis-cyclopentadienyls of transition metals from the first row, have been obtained from measurements of their energies of combustion (Ref. 19, 20). The derived $\bar{D}(M-C p)$ values are included in Table 2, in which available bond dissociation energy values for metal-carbon bonds of different types are collected together for comparison. The gaps in this table out number the data items, some of which are subject to considerable uncertainty (bracketted values). Nevertheless, a clear pattern is discernable, which indicates that the strongest metal-carbon bonds occur in the metal carbide diatomic molecules, followed by $\mathrm{M}-\mathrm{Cp}>$ $\mathrm{M}$-arene $>\mathrm{M}-\mathrm{CH}_{3}>\mathrm{M}-\mathrm{CO}$. This pattern matches expectation in that the 'bond-orders' of the metal-carbon bonds diminish in passing from $\mathrm{MC}$ to $\mathrm{MCH}_{3}$; the bond-order rises again at $\mathrm{M}-\mathrm{CO}$, and it is the large reorganization energy of the co ligand on dissociation which effectively 
lowers $\overline{\mathrm{D}}(\mathrm{M}-\mathrm{CO})$.

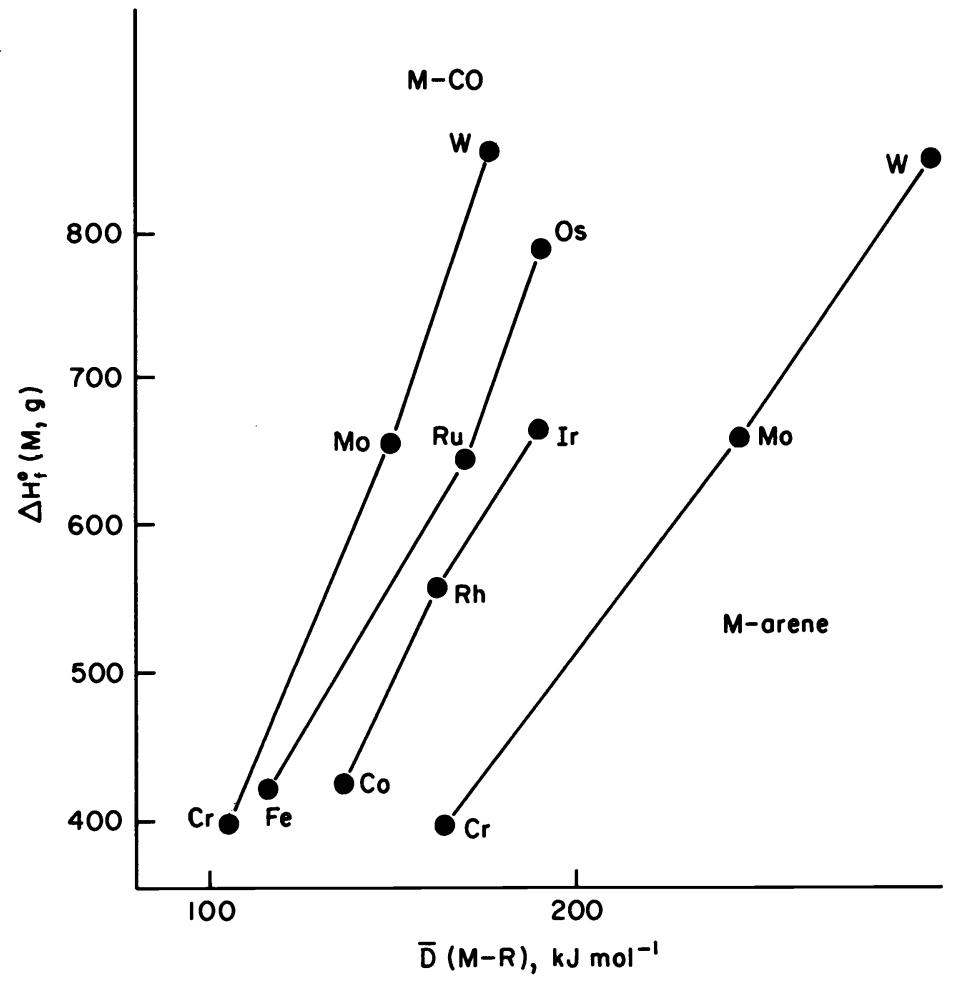

Figure 4. $\bar{D}(M-C O)$ values plotted against $\Delta \mathrm{H}_{\mathrm{f}}^{\mathrm{O}}(\mathrm{M}, \mathrm{g})$

TABLE 2. Metal-carbon bond energies, $\overline{\mathrm{D}}$.

\begin{tabular}{|c|c|c|c|c|c|}
\hline Metal & $D_{0}(M C)$ & $\bar{D}(M-C p)$ & $\bar{D}\left(\mathrm{M}-\mathrm{C}_{6}{ }_{6}{ }_{6}\right)$ & $\overrightarrow{\mathrm{D}}\left(\mathrm{M}-\mathrm{CH}_{3}\right)$ & $\overline{\mathrm{D}}(\mathrm{M}-\mathrm{CO})$ \\
\hline Sc & $<440$ & 360 & - & - & - \\
\hline $\mathrm{Y}$ & $\sim 417$ & 381 & - & - & - \\
\hline $\mathrm{La}$ & 453 & 355 & - & - & - \\
\hline $\mathrm{Ti}$ & $<432$ & (318) & - & $(255-280)$ & - \\
\hline $\mathrm{Zr}$ & $<556$ & (411) & - & $(274-325)$ & - \\
\hline $\mathrm{Hf}$ & $<536$ & $(412)$ & - & $(340)$ & - \\
\hline $\mathrm{V}$ & 419 & 419 & 286 & - & (156) \\
\hline $\mathrm{Nb}$ & 564 & - & - & - & - \\
\hline $\mathrm{Ta}$ & - & - & - & 256 & - \\
\hline $\mathrm{Cr}$ & - & 340 & 164 & - & 105 \\
\hline Mo & 478 & (403) & 245 & (152) & 149 \\
\hline W & - & $(447)$ & 298 & $155(203)$ & 176 \\
\hline $\mathrm{Mn}$ & - & 263 & - & (153) & (93) \\
\hline TC & 561 & - & - & - & - \\
\hline $\mathrm{Re}$ & - & - & - & $(218)$ & (179) \\
\hline $\mathrm{Fe}$ & - & 350 & - & - & 116 \\
\hline $\mathrm{Ru}$ & 645 & - & - & - & (170) \\
\hline Os & 645 & - & - & - & (189) \\
\hline Co & - & 323 & - & - & (133) \\
\hline $\mathrm{Rh}$ & 580 & - & - & - & (160) \\
\hline Ir & 622 & - & - & - & (189) \\
\hline $\mathrm{Ni}$ & - & 298 & - & - & 144 \\
\hline Pd & 430 & - & - & - & - \\
\hline Pt & 606 & $(366)$ & - & $260(213)$ & - \\
\hline
\end{tabular}

LIGAND REPLACEMENT ENTHALPIES

Enthalpies of formation are known for a variety of ligand-substituted metal carbonyls, from which ligand-replacement heats are readily derived. Examples include the replacement of benzene in $\left[\left(\mathrm{C}_{6} \mathrm{H}_{6}\right) \mathrm{Cr}(\mathrm{CO})_{3}\right]$ by a different arene (Ref. 21) and the replacement of $\mathrm{CO}$ in mononuclear carbonyls by a different ligand, such as pyridine or acetonitrile (Ref. 13, 22). 
The displacement enthalpies, $\Delta \mathrm{H}_{1}, \Delta \mathrm{H}_{2}, \Delta \mathrm{H}_{3}$ for

$$
\begin{aligned}
& {\left[\left(\mathrm{C}_{6} \mathrm{H}_{6}\right) \mathrm{Cr}(\mathrm{CO})_{3}, \mathrm{~g}\right]+\text { arene }(\mathrm{g}) \rightarrow\left[\text { (arene) } \mathrm{Cr}(\mathrm{CO})_{3}, \mathrm{~g}\right]+\mathrm{C}_{6} \mathrm{H}_{6}(\mathrm{~g}) ; \Delta \mathrm{H}_{1}} \\
& {\left[\mathrm{M}(\mathrm{CO})_{6}, \mathrm{~g}\right]+\text { ligand }(\mathrm{g}) \rightarrow\left[(\text { ligand }) \mathrm{M}(\mathrm{CO})_{5}, \mathrm{~g}\right]+\mathrm{CO}(\mathrm{g}) ; \Delta \mathrm{H}_{2}} \\
& {\left[\mathrm{M}(\mathrm{CO}){ }_{6}, \mathrm{~g}\right]+3 \text { ligand }(\mathrm{g}) \rightarrow\left[(\text { ligand })_{3} \mathrm{M}(\mathrm{CO})_{3}, \mathrm{~g}\right]+3 \mathrm{CO}(\mathrm{g}) ; \Delta_{3}}
\end{aligned}
$$

are negative if the replacement ligand is more strongly bonded than the displaced ligand, and

\begin{tabular}{|c|c|c|c|c|}
\hline Arene & $\Delta \mathrm{H}_{1}$ & Ligand & $\Delta \mathrm{H}_{2}$ & $\Delta \mathrm{H}_{3}$ \\
\hline $\mathrm{C}_{6} \mathrm{Me}_{6}$ & -26 & $\mathrm{Ph}_{3} \mathrm{P} \quad\left(\right.$ in $\left.\mathrm{W}(\mathrm{CO})_{6}\right)$ & -123 & - \\
\hline Mesitylene & -12 & Piperidine (in $\mathrm{W}(\mathrm{CO})_{6}$ ) & +5 & - \\
\hline $\mathrm{PhNMe}_{2}$ & -3 & Pyridine (in $\mathrm{W}\left(\mathrm{CO}{ }_{6}\right.$ ) & +27 & +15 \\
\hline Toluene & +4 & $\mathrm{CH}_{3} \mathrm{CN}$ (in $\mathrm{W}(\mathrm{CO})_{6}$ ) & - & +26 \\
\hline $\mathrm{PhOCH}_{3}$ & +14 & Pyridine (in Mo $(\mathrm{CO})_{6}$ ) & - & +18 \\
\hline $\mathrm{PhCl}$ & +19 & $\mathrm{CH}_{3} \mathrm{CN}$ (in $\mathrm{Mo}\left(\mathrm{CO}_{6}\right)$ & - & +39 \\
\hline Naphthalene & +26 & Piperidine (in $\mathrm{Cr}(\mathrm{CO})_{6}$ ) & +8 & 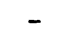 \\
\hline $\mathrm{PhCOCH}_{3}$ & +44 & Pyridine (in $\mathrm{Cr}(\mathrm{CO})_{6}$ ) & +28 & - \\
\hline $\mathrm{PhCOOCH}_{3}$ & +64 & Ethylene (in $\mathrm{Fe}(\mathrm{CO})_{5}$ ) & +22 & \\
\hline
\end{tabular}
are positive when the reverse is the case. Values of $\Delta \mathrm{H}_{1}, \Delta \mathrm{H}_{2}$ and $\Delta \mathrm{H}_{3}$ are given in Table 3 .

TABLE 3. Ligand replacement enthalpies (kJ mol ${ }^{-1}$ )

The weakness of methylbenzoate and acetophenone (relative to benzene) is consistent with electron withdrawal from the ring by the $\cdot \mathrm{COCH}_{3}$ and $\cdot \mathrm{COOCH}_{3}$ substituent groups; the relative strength of methyl-substituted benzenes, and of dimethylaniline is likewise indicative of electron donation to the ring by alkyl and $\cdot \mathrm{NMe}_{2}$ substituents. The $\Delta \mathrm{H}_{2}, \Delta \mathrm{H}_{3}$ values show that phosphine donors are stronger than nitrogen donors, and that co donor is at least as strong as pyridine, and stronger than methyl cyanide and ethylene. Recent studies on complexes $\left[\mathrm{L}_{2} \mathrm{PtCl}_{2}\right]$ and $\left[\mathrm{L}_{2} \mathrm{PdCl}_{2}\right]$ have also shown the phosphine donors as appreciably stronger than nitrogen donors (Ref. 23), the $\overline{\mathrm{D}}\left(\mathrm{L}-\mathrm{PtCl}_{2}\right.$ ) values diminishing along the series $\mathrm{L}=\mathrm{PiPr}_{3}>$ $\mathrm{P}\left(\mathrm{C}_{6} \mathrm{H}_{11}\right)_{3}>\mathrm{PEt}_{3}>\mathrm{PPh}_{3}>$ olefin (in cyclo-octa 1,5 diene) $>$ pyridine $>$ methylamine $>\mathrm{NH}_{3}$; the $\overline{\mathrm{D}}\left(\mathrm{L}-\mathrm{PdCl}_{2}\right)$ values for $\mathrm{L}=\mathrm{PPh}_{3}$, olefin and $\mathrm{MeCN}$ are of similar magnitude to one another.

\section{TRANSITION METAL MOLECULE-IONS}

Beauchamp and co-workers $(24,25)$ have reported ion-beam studies of reactions of the type $\mathrm{M}^{+}+\mathrm{R}_{2} \rightarrow \stackrel{+}{\mathrm{MR}}+\mathrm{R}$, for the transition-metal ions $\mathrm{M}^{+}=\mathrm{Cr}^{+}, \mathrm{Mn}^{+}, \mathrm{Fe}^{+}, \mathrm{Co}^{+}, \mathrm{Ni}^{+}$with $\mathrm{R}_{2}=\mathrm{H}_{2}$ $\mathrm{C}_{6} \mathrm{H}_{6}, \mathrm{C}_{2} \mathrm{H}_{4}$ and $\mathrm{O}_{2}$, leading to values for the dissociation energies $\mathrm{D}\left(\mathrm{M}^{+}-\mathrm{H}\right), \mathrm{D}\left(\mathrm{M}^{+}-\mathrm{CH}_{3}\right)$, $\mathrm{D}\left(\mathrm{M}^{+}-\mathrm{CH}_{2}\right)$ and $\mathrm{D}\left(\mathrm{M}^{+}-\mathrm{O}\right)$. These relate to the ground-states of the ions, $\mathrm{Cr}^{+} \mathrm{d}^{5}, \mathrm{Mn}^{+} \mathrm{d}^{5} \mathrm{~S}$, $\mathrm{Fe}^{+} d^{6} \mathrm{~S}^{2} \mathrm{Co}^{+} d^{8}$ and $\mathrm{Ni}^{+} d^{9}$. Beauchamp has argued that the configurations $d^{\mathrm{n}}$ are less able to form strong $\sigma$-bonds than the configurations $\mathrm{d}^{\mathrm{n}-1} \mathrm{~s}$, reflected by the relatively low $\mathrm{D}(\stackrel{+}{\mathrm{M}}-\mathrm{H}), \stackrel{\mathrm{D}\left(\stackrel{+}{\mathrm{M}}-\mathrm{CH}_{3}\right)}{\text { and }} \mathrm{D}\left(\stackrel{+}{\mathrm{M}}-\mathrm{CH}_{2}\right)$ values for $\stackrel{+}{\mathrm{M}}=\stackrel{+}{\mathrm{C}}$, $\stackrel{+}{\mathrm{C}}$ and $\mathrm{N}_{i}^{+}$. In Table 4 , the experimental $\mathrm{D}_{\circ}$ values are given along side $\mathrm{D}_{0}^{*}$ values, measured with respect to the lowest-lying state, $\mathrm{d}^{\mathrm{n}-1} \mathrm{~s}$, of the ions from $\mathrm{Cr}^{+}, \mathrm{Co}^{+}$and $\mathrm{Ni}^{+}$. Comparison of $\mathrm{D}_{0}^{*}(\mathrm{M}-\mathrm{X})$ with $\left.\mathrm{D}_{0}(\mathrm{M}-1)-\mathrm{X}\right)$ of iso-electronic neutral molecules shows these to be of similar magnitude, in the few cases where comparison is possible.

\section{METAL-METAL BONDS}

The dissociation-energies, $\mathrm{D}_{\mathrm{O}}\left(\mathrm{M}_{2}\right)$, of some 50 homonuclear dimetals have been reported (Refs. 2,3). The values for diatoms of the lst and 2nd row elements, plotted against atomic number (Fig. 5), rise and fall as the valences of the atoms change in passing from $\mathrm{Li}$ to $\mathrm{Cl}$. The plot (Fig. 6) of $\mathrm{D}_{(}\left(\mathrm{M}_{2}\right)$ for the lst row transition metals (from $\mathrm{K}$ to $\mathrm{Zn}$ ) shows no such regularity. The higher valence atoms $(\mathrm{Cr}, \mathrm{Mn}, \mathrm{Fe}, \mathrm{Co})$ have $\mathrm{D}_{\mathrm{O}}\left(\mathrm{M}_{2}\right)$ values which are less 
TABLE 4. Dissociation energies in molecule-ions

\begin{tabular}{|c|c|c|c|}
\hline Compound & $D_{0}\left(M^{+}-X\right)$ & $D_{0}^{*}\left(M^{+}-X\right)$ & Comparison \\
\hline $\mathrm{Cr}^{+}$ & $146 \pm 17$ & $289^{*}$ & \\
\hline $\mathrm{Cr}^{+} \mathrm{CH}_{3}$ & $155 \pm 29$ & $298^{*}$ & \\
\hline $\mathrm{Cr}^{+}=\mathrm{CH}_{2}$ & $272 \pm 29$ & $415^{\star}$ & vc 419 \\
\hline $\mathrm{Mn}^{+} \mathrm{H}$ & $222 \pm 12$ & 222 & $\mathrm{CrH} \quad(275 \pm 50)$ \\
\hline $\mathrm{Mn}^{+} \mathrm{CH}_{3}$ & $297 \pm 29$ & 297 & \\
\hline $\mathrm{Mn}^{+}=\mathrm{CH}_{2}$ & $393 \pm 25$ & 393 & \\
\hline $\mathrm{Fe}^{+} \mathrm{H}$ & $243 \pm 21$ & 243 & $\mathrm{MnH}$ (241) \\
\hline $\mathrm{Fe}^{+} \mathrm{CH}_{3}$ & $285 \pm 17$ & 285 & \\
\hline $\mathrm{Fe}^{+}=\mathrm{CH}_{2}$ & $402 \pm 21$ & 402 & \\
\hline $\mathrm{Co}^{+} \mathrm{H}$ & $218 \pm 17$ & $256^{*}$ & \\
\hline $\mathrm{Co}^{+} \mathrm{CH}_{3}$ & $255 \pm 12$ & $293^{*}$ & \\
\hline $\mathrm{Co}^{+}=\mathrm{CH}_{2}$ & $356 \pm 29$ & $393^{*}$ & \\
\hline $\mathrm{Ni}^{+} \mathrm{H}$ & $180 \pm 8$ & $280^{*}$ & $\mathrm{COH}$ (309) \\
\hline $\mathrm{Ni}^{+} \mathrm{CH}_{3}$ & $201 \pm 21$ & $301{ }^{*}$ & \\
\hline $\mathrm{Ni}^{+}=\mathrm{CH}_{2}$ & $360 \pm 25$ & $460^{*}$ & \\
\hline $\mathrm{Cu}^{+} \mathrm{H}$ & $(<60)$ & $<(320)$ & NiH 297 \\
\hline $\mathrm{Zn}^{+} \mathrm{H}$ & 241 & 241 & $\mathrm{CuH} 264$ \\
\hline $\mathrm{Zn}^{+} \mathrm{CH}_{3}$ & 280 & 280 & \\
\hline $\mathrm{Cd}^{+} \mathrm{H}$ & 203 & 203 & $\mathrm{AgH} 220$ \\
\hline $\mathrm{Cd}^{+} \mathrm{CH}_{3}$ & 226 & 226 & \\
\hline $\mathrm{Hg}^{+} \mathrm{H}$ & 289 & 289 & AuH 311 \\
\hline $\mathrm{Hg}^{+} \mathrm{CH}_{3}$ & 293 & 293 & \\
\hline
\end{tabular}

than $\mathrm{D}_{\mathrm{O}}\left(\mathrm{Cu}_{2}\right)$, deriving from monovalent $\mathrm{Cu}, \mathrm{d}^{10} \mathrm{~s}$. The very weak bonding in Group II dimetals is essentially van der waals in character, consistent with the zero-valent ground-states $\left({ }^{1} s, s^{2}\right)$ of the atoms, and the large promotion energies needed to achieve a divalent state (e.g. $\left.{ }^{3} \mathrm{P}, \mathrm{sp}\right)$. The weak binding in $\mathrm{Mn}_{2}$ is less easily explained; the ground-state, ${ }^{6} \mathrm{~S}$, $\mathrm{d}^{5} \mathrm{~s}^{2}$, of the Mn atom, is capable in principle of forming a quintuple $\mathrm{Mn}-\mathrm{Mn}$ bond, and the weakness of the bond formed suggests that d-electrons can only form weak bonds with one another. The evidence from other transition dimetals (e.g. $\mathrm{Nb}_{2}, \mathrm{D}_{\mathrm{O}}=(503 \pm 10) \mathrm{kJ} \mathrm{mol}^{-1}$, deriving from ground-state $\mathrm{Nb},{ }^{6} \mathrm{D}, \mathrm{d}^{4} \mathrm{~s}$ ) contradicts this; an alternative suggestion (Ref. 25) is that the configuration $d^{n} s^{2}$ has less linear bonding-power than $d^{n+l} s$. In the case of $\mathrm{Mn}_{2}$, the excitation energy needed to reach ${ }^{6} \mathrm{D}, \mathrm{d}^{6} \mathrm{~s}\left(208 \mathrm{~kJ} \mathrm{~mol}^{-1}\right)$ is probably prohibitive. On the other hand the excitation energies $d^{n} s^{2} \rightarrow d^{n+l} s$ for $\mathrm{Fe}$, Co and $\mathrm{Ni}$ are not large, and the dimetals of these could well originate from excited $d^{n+l} s$ configurations. The bindingenergies, $\mathrm{D}_{\mathrm{O}}^{*}\left(\mathrm{M}_{2}\right)$ for $\mathrm{Ni}_{2}, \mathrm{Co}_{2}$ and $\mathrm{Fe}_{2}$, measured with respect to the lowest-lying configurations, $d^{n+1} s$, are plotted by the broken line in Figure 6 , and change with valence in the expected manner.

The broken curve in Figure 6, would however, imply $\mathrm{D}_{0}^{*}$ for $\mathrm{Cr}_{2}>300 \mathrm{~kJ}$ mol ${ }^{-1}$, which is twice as large as the experimental value. The spectroscopic evidence (Ref. 26) clearly indicates a very short bond-length $\left(r_{e}=1.68 \stackrel{\circ}{A}\right)$, consistent with sextuple bonding, and the ground-state configuration, ${ }^{1} \Sigma_{g}^{+}$is in accord with this. Curiously, it is the very shortness of the bond in $\mathrm{Cr}_{2}$ which could account for the seemingly low value of $\mathrm{D}_{0}$ - in that the $\sigma$-component of the sextuple bond is under considerable strain, compressed from its normal length by as much $0.7 \stackrel{\circ}{\mathrm{A}}$, and no longer very effective energetically as a binding agent. A factor of relevance to this suggestion is that the bond-energy contribution of the quadruple-bond, $\mathrm{Cr}-\mathrm{Cr}$, in a number of organic complexes of dichromium appears to be at least as large as $\mathrm{D}_{0}\left(\mathrm{Cr}_{2}\right)$, although the $\mathrm{Cr}-\mathrm{Cr}$ bond-lengths in these are longer than in the dimetal. In these complexes 


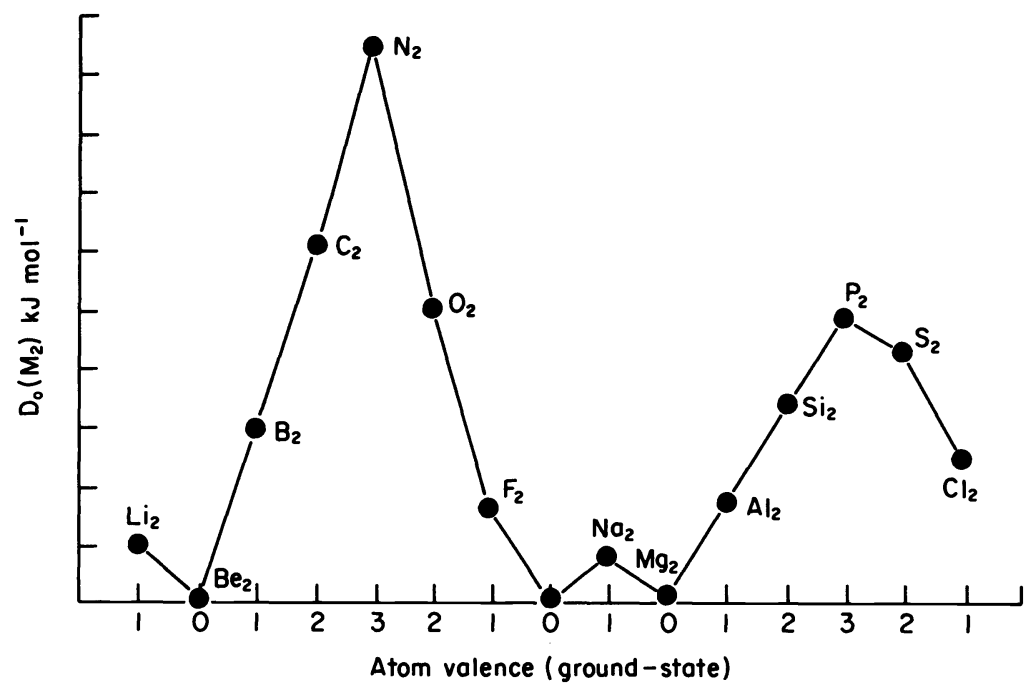

Figure 5. $\mathrm{D}_{\circ}\left(\mathrm{M}_{2}\right)$ values from $\mathrm{Li}_{2}$ to $\mathrm{Cl}_{2}$.

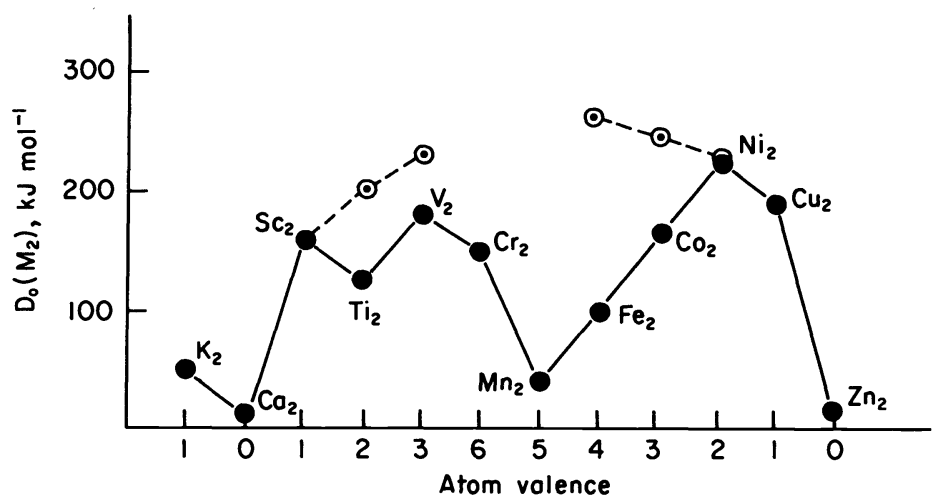

Figure 6. $\mathrm{D}_{0}\left(\mathrm{M}_{2}\right)$ values from $\mathrm{K}_{2}$ to $\mathrm{Zn}_{2}$.

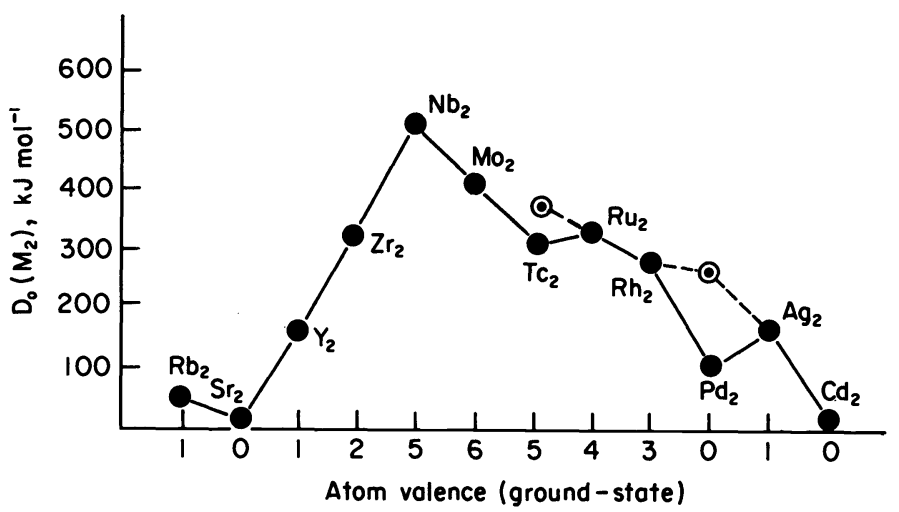

Figure 7. $\mathrm{D}_{\mathrm{o}}\left(\mathrm{M}_{2}\right)$ values from $\mathrm{Rb}_{2}$ to $\mathrm{Cd}_{2}$

(dichromium tetraacetate, $\mathrm{Cr}_{2}(\mathrm{mhp})_{4}, \mathrm{Cr}_{2}(\mathrm{DMP})_{4}$, Ref. 27) the ligand - $\mathrm{Cr}$ bonds are directed at right-angles to the $\mathrm{Cr}-\mathrm{Cr}$ bond, and the quadruple bond need not involve a $\sigma$-component. The broken curve through $\mathrm{Sc}_{2}, \mathrm{Ti}_{2}$ and $\mathrm{v}_{2}$ is tentative; the ground-state of $\mathrm{Sc}_{2}$, from spectroscopic studies by Knight $(28)$, is identified as the quintet ${ }^{5} \sum$, and originates from excited Sc. The ground-state of $v_{2}$ is reported to be ${ }^{3} \Sigma_{g}^{-}$(Ref. 29), and the bond-length $(1.77 \stackrel{\circ}{\AA})$ implies a high bond-order corresponding to a quintuple bond.

Figure 7 plots the $\mathrm{D}_{\mathrm{O}}\left(\mathrm{M}_{2}\right)$ values for the second-row transition metals from $\mathrm{Rb}$ to Cd, showing the changing valence of the ground-states of the metal atoms. The low $\mathrm{D}_{0}$ values for $\mathrm{Sr}_{2}$ and $\mathrm{Cd}_{2}$ reflect predominantly van der Waals interactions in these diatoms, deriving from the zero-valent ground-state atoms, but the $\mathrm{D}_{0}$ in $\mathrm{Pd}_{2}$ implies chemical bonding, and it seems clear that the low-lying $d^{9} \mathrm{~s}$, divalent state of $\mathrm{Pd}\left({ }^{3} \mathrm{D}_{3}, \mathrm{~d}^{9} \mathrm{~s}\right.$, lies only $78.5 \mathrm{~kJ}$ mol ${ }^{-1}$ above 
the zero-valent ground-state, ${ }^{1} \mathrm{~S}, \mathrm{~d}^{10}$, of the $\mathrm{Pd}$ atom) is the parent from which the dimetal derives. The $\mathrm{D}_{\circ}$ values for $\mathrm{Ru}_{2}, \mathrm{Ti}_{2}$ and $\mathrm{Zr}_{2}$ are estimates only.

The broken curve refers to $\mathrm{D}_{0}^{*}$ values, relating to $\mathrm{d}^{\mathrm{n}+1} \mathrm{~s}$ valence-states of the atoms. Bondlengths and ground-state multiplicities are not yet determined for the second-row transition dimetals.

The available knowledge of dissociation energies, bond-lengths and ground-state multiplicities is insufficient to reach firm conclusions on the factors that influence metalmetal binding energy, but the variations with transition metals (and lanthanides) are irregular, and do not change with the ground-state valence of the metal atom in a regular manner. The role of "valence-state" is frequently ignored by thermochemists in evaluating "bond energies" (we do not usually relate the energies of carbon bonds in organic compounds to a tetravalent carbon atom!), and transition metal bonds seem to expose a real need to do so.

\section{REFERENCES}

1. G. Pilcher and H.A. Skinner, Chap.2 in The Chemistry of the Metal-Carbon Bond, (F.R. Hartley and S. Patai, Eds.), J. Wiley (1982).

2. K.A. Gingerich, Faraday Symposium of the Chem.Soc., No.14, Diatomic Metals and Metallic Clusters, 109-125 (1980).

3. K.P. Huber and G. Herzberg, Molecular Spectra and Molecular Structure, IV : Constants of Diatomic Molecules, Van Nostrand Reinhold, New York (1979).

4. J.B. Pedley and E.M. Marshall, Thermochemical Data for Gaseous Monoxides, in the Industrial Use of Thermochemical Data, (T.I. Barry, Ed.), The Royal Soc. of Chemistry, p.83, London (1980).

5. J.D. Cox and G. Pilcher, Thermochemistry of Organic and Organometallic Compounds, Chap.7, Academic Press, London (1970).

6. Thermodynamic Properties of Individual Substances, (V.P. Glushko, L.V. Gurvich et al, Eds.), Vols.I-IV, Akad.Nauk., Moscow (1978-82).

7. Thermal Constants of Substances, (V.P. Glushko, V.A. Medvedev, G.A. Bergman, L.V. Gurvich et al., Eds), Vols.I-X, Acad.Sci.USSR, VINITI, Moscow (1965-82).

8. L.V. Gurvich, G.V. Karachevtsev, V.N. Kondratiev, Yu. A. Lebedev, V.A. Medvedev, V.K. Potapov and Yu. S. Hodiev, Energies of Dissociation of Chemical Bonds, Akad.Nauk.USSR, Moscow (1974).

9. NBS Tables of Chemical Thermodynamic Properties, J.Phys.Chem.Ref.Data, Vol.11, Supplement No.2 (1982).

10. M.N. Jones and H.A. Skinner, Ann.Rep.Chem.Soc., C, Chap.2, 'Thermochemistry', (1982).

11. G. Pilcher, in Thermochemistry and its Application to Chemical and Biochemical Systems, NATO ASI Series, C 119, p.353-382, D. Reidel Publishing Co., Dordrecht, (1984).

12. M.F. Lappert, D.S. Patel and J.B. Pedley, J.C.S. Chem.Comm., 830, (1975) .

13. K.E. Lewis, D.M. Golden and G.P. Smith, J.Ä.Chem.Soc., (in Press).

14. H.A. Skinner, Trans.Faraday Soc., 45, 20 (1949).

15. H.A. Skinner and F.H. Sumner, J.Inorg.Nucl.Chem., 4, 245 (1957).

16. J.A. Connor, H.A. Skinner and Y. Virmani, Faraday Symposia of the Chem.Soc., No.8, p.18 (1973).

17. J.A. Connor, J.A. Martinho-Simoes, H.A. Skinner and M.T. Zafarani-Moattar, J.Organomet.Chem., 179, 331 (1979).

18. J.A. Connor, N.I. El-Saied, J.A. Martinho-Simoes and H.A. Skinner, J.Organomet.Chem., 212, 405 (1981).

19. C.G. Devyatykh, I.B. Rabinovitch, V.I. Tel'noi, G.K. Boisov and L.F. Zyazina, Dokl.Akad.Nauk., SSSR, 217, 673 (1974).

20. V.I. Tel'noi, K.V. Kirynov, V.I. Ermolaev and I.B. Rabinovitch, Dokl.Akad.Nauk. SSSR, 209, 197 (1973).

21. G. Al-Takhin, J.A. Connor, H.A. Skinner and M.T. Zafarani-Moattar, J.Organomet.Chem. , 260, 189 (1984).

22. G. Al-Takhin, J.A. Connor, G. Pilcher and H.A. Skinner, J.Organomet.Chem., 265, 263 (1984).

23. G. Al-Takhin, H.A. Skinner and A.A. Zaki, J.C.S. Dalton Trans., 2323 (1983) and 371 (1984).

24. P.B. Armentrout and J.L. Beaumont, Chem.Phys., 50, 37 (1980); J.Amer.Chem.Soc., 103, 784 and 6628 (1981); J.Chem.Phys., 74, 2819 (1981).

25. P.B. Armentrout, L.F. Halle and J.L. Beaumont, J.Amer.Chem.Soc., 103, 962, 6501 and 6624 (1981) ; J.Chem.Phys., 76, 2449 (1982).

26. D.L. Michalopoulus, E. Geusic, S.G. Hansen, D.E. Powers and R.E. Smalley, J.Phys.Chem. , 86, 3914 (1982).

27. K.J. Cavell, C.D. Garner, J.A. Martinho-Simoes, G. Pilcher, H. Al-Samman, H.A. Skinner, G. Al-Takhin, I.B. Walton and M.T. Zafarani-Moattar, J.C.S. Faraday Trans., 77, 2927 (1981).

28. L.B. Knight, Jr., R.J. Van Zee, w. Weltner, Jr., Chem.Phys.Lett., 94, 296 (1983).

29. P.R.R. Langridge-Smith, M.D. Morse, G.P. Hansen, R.E. Smalley and A.J. Merer, J.Chem.Phys., 80, 593 (1984). 